\title{
JENIS MATERI AJAR CERITA PENDEK \\ DALAM BUKU SISWA BAHASA INDONESIA SMA DAN RELEVANSINYA DENGAN KURIKULUM 2013
}

\author{
Oleh \\ Main Sufanti, Aziza Riangsari, Fransiska Wulandari \\ Program Studi Pendidikan Bahasa Indonesia, FKIP \\ Universitas Muhammadiyah Surakarta \\ main.sufanti@ums.ac.id
}

\begin{abstract}
This study aims to: (1) describe the type of teaching materials in the book of short stories Indonesian high school students, and (2) describe the relevance of the types of teaching materials with curriculum competencies 2013. The research is a qualitative descriptive. The data in this study of words, phrases, sentences, and paragraphs contained in the book Students and competencies in the curriculum of 2013. Sources of data in the form of books Indonesian student, Self-Expression and Academic classes X, XI, and XII published by Kemendikbud 2014 and KI - KD Indonesian High School Curriculum 2013. the data was collected with the technique see and note. Technique authenticity of data used triangulation theory. Techniques of analysis is a semiotic readings and comparative. The results of this study as follows. (1) Type of teaching materials in the book of short stories Indonesian students include cognitive aspects of teaching materials which consist of facts, concepts, principles and procedures, teaching materials affective, and psychomotor aspects of teaching materials. Teaching material facts such as text stories, question the factual content of short stories, and identify the vocabulary and sentences in short stories. Teaching materials in the form of understanding the concept, features, and short story structure, linguistic elements, the socio authors, linkage content of short stories with reality, and the events of monologues and dialogue. Teaching material principle in the form of short stories structure. Teaching material procedure that is the creative process of writing and the steps to write short stories. Type affective aspect of teaching materials in the form of questions related to attitude, comments, opinions, and expectations after reading or writing short stories before. The teaching materials in the form of psychomotor task of building, abstracting, converting, producing, and editing text stories. (2) All the teaching materials relevant to the competence of 2013. Curriculum Teaching materials cognitive aspects in accordance with KD in the KI-3 are competence of knowledge. Affective aspects of teaching materials in accordance with the KI $K D-2$ is the social aspect. The teaching materials on psychomotor aspects relevant to the KI KD 4 is competency skills.
\end{abstract}

Keywords: teaching materials, short stories, books students, Curriculum 2013

\begin{abstract}
ABSTRAK
Penelitian ini bertujuan untuk: (1) mendeskripsikan jenis materi ajar cerpen dalam buku siswa Bahasa Indonesia SMA, dan (2) mendeskripsikan relevansi jenis materi ajar tersebut dengan kompetensi Kurikulum 2013. Jenis penelitian ini adalah kualitatif deskriptif. Data dalam penelitian ini berupa kata, frase, kalimat, dan paragraf yang terdapat dalam buku Siswa dan kompetensi dalam Kurikulum 2013. Sumber data berupa buku siswa Bahasa Indonesia,
\end{abstract}


Ekspresi Diri dan Akademik kelas X,XI, dan XII yang diterbitkan oleh Kemendikbud 2014 dan KI - KD Bahasa Indonesia SMA Kurikulum 2013. Data-data tersebut dikumpulkan dengan teknik simak dan catat. Teknik keabsahan data digunakan trianggulasi teori. Teknik analisisnya adalah pembacaan semiotik dan komparatif.Hasil penelitian ini sebagai berikut. (1) Jenis materi ajar cerpen dalam buku siswa Bahasa Indonesia meliputi materi ajar aspek kognitif yang terdiri fakta, konsep, prinsip, dan prosedur, materi ajar aspek afektif, dan materi ajar aspek psikomotor. Materi ajar fakta berupa teks cerpen, pertanyaan faktual isi cerpen, dan mengidentifikasi kosa kata dan kalimat dalam cerpen. Materi ajar konsep berupa pengertian, ciri-ciri, dan struktur cerpen, unsur kebahasaan, latar belakang sosio pengarang, keterkaitan isi cerpen dengan kenyataan, dan peristiwa monologis dan dialogis. Materi ajar prinsip berupa struktur cerpen. Materi ajar prosedur yaitu proses kreatif penulisan dan langkah-langkah menulis cerpen. Jenis materi ajar aspek afektif berupa pertanyaan-pertanyaan yang berkaitan dengan sikap, tanggapan, pendapat, dan harapan setelah membaca atau sebelum menulis cerpen. Adapun materi ajar psikhomotor berupa tugas membangun, mengabstraksi, mengonversi, memproduksi, dan menyunting teks cerpen. (2) Semua materi ajar itu relevan dengan kompetensi Kurikulum 2013. Materi ajar aspek kognitif sesuai dengan KD pada KI-3 yaitu kompetensi pengetahuan. Materi ajar aspek afektif sesuai dengan KD pada KI-2 yaitu aspek sosial. Adapun materi ajar pada aspek psikhomotor relevan dengan KD pada KI 4 yaitu kompetensi keterampilan.

Kata kunci: bahan ajar, cerpen, buku siswa, Kurikulum 2013

\section{PENDAHULUAN}

Cerpen (cerita pendek) merupakan bentuk karya sastra yang bersifat fiksi. Poe

(dalam Nurgiyantoro, 2010: 10) mengatakan bahwa cerpen adalah cerita yang selesai dibaca dalam sekali duduk, kira-kira berkisar antara setengah sampai dua jam. Rosidi (dalam Tarigan, 2011: 180) cerpen adalah cerita yang pendek dan merupakan suatu kebulatan ide. Dengan demikian, cerpen merupakan fiksi yang dapat dibaca dalam waktu yang singkat dan ceritanya sudah bulat.
Cerpen merupakan salah satu materi ajar dalam mata pelajaran Bahasa Indonesia di sekolah. Menurut Haryati (2013:10) materi ajar adalah pengetahuan, keterampilan, dan sikap yang harus diajarkan oleh guru dan dipelajari siswa sebagai sarana untuk mencapai indikatorindikator yang telah ditetapkan dalam standar kompetensi dan kompetensi dasar, kemudian dievaluasi dengan menggunakan perangkat penilaian yang disusun berdasarkan indikator pencapaian hasil belajar. 
Selama ini cerpen diajarkan sejak di SD hingga SMA. Cerpen sangat mungkin dijadikan materi ajar secara lengkap karena bentuknya yang pendek sehingga mudah dimuat di dalam buku ajar. Hal ini sesuai dengan pendapat Nurgiyantoro (2010:11) bahwa cerpen menuntut penceritaan yang serba ringkas, tidak sampai pada detil-detil khusus yang kurang penting yang lebih bersifat memperpanjang cerita. Oleh karena bentuknya yang ringkas tersebut, cerpen lebih efisien dijadikan sebagai materi ajar dalam pembelajaran.

Materi ajar cerpen dapat dijumpai pada buku siswa Bahasa Indonesia SMA Kurikulum 2013. Buku siswa atau buku teks Kurikukulum 2013 yang diterbitkan oleh Kemendikbud merupakan buku yang dinyatakan layak dijadikan sebagai sumber belajar, pedoman, ataupun referensi baik bagi guru maupun siswa dalam proses pembelajaran. Begitu pula, buku siswa Bahasa Indonesia untuk SMA kelas X, XI, dan XII yang berjudul Bahasa Indonesia, Ekspresi Diri dan Akademik.
Mengingat pentingnya materi ajar dalam buku teks yang berfungsi sebagai sumber informasi, referensi, buku acuan atau pedoman dalam pembelajaran, maka tentu saja materi dalam bahan ajar yaitu buku teks harus relevan dengan kurikulum yang berlaku. Dalam penyusunannya buku teks harus berdasarkan pada kurikulum karena buku teks merupakan penjabaran dari kurikulum, dan kurikulum itu berfungsi sebagai jembatan dalam mencapai tujuan pendidikan. Dengan demikian, jika materi ajar telah sesuai atau relevan dengan kurikulum, maka nantinya tujuan pendidikan dapat dicapai dengan baik. Namun sebaliknya, jika materi ajar tidak sesuai maka tujuan pembelajaran tidak akan dicapai.

Reigeluth (dalam Mudini dan Syamsurizal,2011:16) meyatakan bahwa sejalan dengan berbagai jenis aspek standar kompetensi, materi pembelajaran juga dapat dibedakan menjadi jenis materi aspek kognitif, afektif, dan psikomotorik. Wardani dalam Pannen dan Puspitasari 
(2005:59) menyatakan bahwa materi ajar meliputi: informatif, konseptual, prosedural, keterampilan, dan sikap.

Materi pembelajaran aspek kognitif secaraterperinci dapat dibagi menjadi empat jenis, yaitu: fakta, konsep, prinsip dan prosedur (Reigeluthdalam Mudini dan syamsurizal,2011:16). Hal ini sesuai juga dengan Standar Proses (Kemdikbud, 2016) yang mencantumkan bahwa materi pokok dalam silabus memuat fakta, konsep, prinsip, dan prosedur yangrelevan, dan ditulis dalam bentuk butir-butir sesuai denganrumusan indikator pencapaian kompetensi.

Reigeluth (dalam Mudini dan Syamsurizal,2011:16) meyatakan bahwa materi pembelajaran aspek afektif meliputi: pemberian respon, penerimaan(apresisasi), internalisasi, dan penilaian. Kosasih (2014:34) menyatakan bahwa sikap atau nilai merupakan hasil belajar sebagai efek pengiring terkait dengan materi pokok. Sikap-sikap yang dimaksud, misalnya: kedisiplinan, tanggung jawab, dan responsif.

Adapun materi pembelajaran aspek motorikterdiri dari gerakan awal, semi rutin, dan rutin (Reigeluth dalam Mudini dan Syamsurizal,2011:16). Widoyoko (2014:45) menyatakan bahwa aspek keterampilan merupakan hasil belajar yang pencapaiannya melibatkan otot dan kekuatan fisik. Dengan kata lain, psikomotor adalah ranah yang berhubungan dengan aktivitas fisik. Keterampilan ini menunjukkan tingkat keahlian seseorang dalam melaksanakan suatu tugas tertentu.

Materi ajar di dalam buku teks penting untuk diteliti karena buku teks merupakan sumber utama dalam pembelajaran. Sufanti (2003) menemukan bahwa materi sastra yang diajarkan di sekolah adalah materi yang tercantum di dalam buku teks atau LKS. Informasi ini membuktikan bahwa di dalam mengajar, guru sangat tergantung kepada materi ajar dalam buku teks yang smenggunakan 
bahan ajar yang sudah disusun oleh penulis. Oleh karena itu, materi ajar dalam buku teks berperan penting dalam pencapaian tujuan pembelajaran.

Artikel ini adalah hasil penelitian yang mendeskripsikan tentang: (1) jenis materi ajar cerpen dalam buku siswa Bahasa Indonesia SMA, dan (2) relevansi jenis materi ajar tersebut dengan kompetensi dalam Kurikulum 2013.

\section{METODE PENELITIAN}

Penelitian ini adalah penelitian kualitatif deskriptif. Data berupa kata, frase, kalimat, dan paragraf yang terdapat dalam buku siswa Bahasa Indonesia dan kompetensi dalam Kurikulum 2013. Sumber data dalam penelitian ini berupa buku siswa Bahasa Indonesia, Ekspresi Diri dan Akademik kelas X, XI, dan XII yang diterbitkan oleh Kemendikbud 2014 dan $\mathrm{KI}$ - KD mata pelajaran Bahasa Indonesia Kurikulum 2013. Teknik pengumpulan datanya adalah teknik pustaka dan teknik simak-catat. Triangulasi teoritis sebagai teknik keabsahan data. Analisis data menggunakan teknik pembacaan semiotik dan komparatif.

\section{HASIL PENELITIAN DAN PEMBAHASAN} Hasil penelitian meliputi dua temuan yaitu jenis materi ajar cerpen dalam buku siswa Bahasa Indonesia SMA dan relevansi materi ajar tersebut dengan kompetensi dalam Kurikulum 2013.

\section{Jenis Materi Ajar Cerpen dalam Buku Siswa Bahasa Indonesia SMA}

Materi ajar cerpen dalam ketiga buku ini ditemukan pada buku siswa kelas XI , pada pelajaran I dan pelajaran 6. Pada pelajaran I seluruh materi ajarnya berkaitan dengan cerpen, namun pada pelajaran 6 hanya ada satu sub bab yang berkaitan dengan cerpen yaitu mengubah teks cerita ulang menjadi teks cerpen.

Materi ajar cerpen dalam buku siswa ini dianalisis dengan teori Reigeluth (dalam Mudini dan Syamsurizal,2011:16;) dan Kurniawan (2011:117) yang menyatakan bahwa materi ajar dapat dibedakan menjadi jenis materi aspek 
kognitif,afektif, dan psikomotorik. Materi

pembelajaran aspek kognitif terdirifakta,

konsep, prinsip, dan prosedur.

Hasil analisis ditemukan bahwa materi ajar cerpen dalam buku ini meliputi: materi ajar pada aspek kognitif, afektif, dan psikomotor sebagai berikut.

a. Jenis Materi Ajar Kognitif

Jenis materi ajar cerpen aspek

kognitif dalam buku siswa ini meliputi:

fakta, konsep, prinsip, dan prosedur.
1) Fakta

Fakta adalah segala hal yang bewujud kenyataan dan kebenaran, meliputi nama-nama obyek, peristiwa sejarah, lambang, nama tempat, nama orang, nama bagian atau komponen suatu benda, dan sebagainya(Reigeluth dalam Mudini dan Syamsurizal,2011:16). Datadata materi ajar cerpen dalam buku siswa ini yang berupa fakta adalah sebagai berikut.

Tabel 1: Materi Ajar Berupa Fakta

\begin{tabular}{|c|l|c|}
\hline No. & \multicolumn{1}{|c|}{ Data } & Halaman \\
\hline 1 & Teks cerpen berjudul “Juru Masak" karya Damhuri Muhammad & 7 \\
\hline 2 & Pertanyaan-pertanyaan berkaitan dengan isi bacaan & 11 \\
\hline 3 & Analisis fakta cerita & 13 \\
\hline 4 & $\begin{array}{l}\text { Mencari kosa kata yang jarang digunakan dalam keseharian dan } \\
\text { mengartikannya berdasarkan kamus }\end{array}$ & $20-21$ \\
\hline 5 & $\begin{array}{l}\text { Menemukan kalimat yang menjelaskan peristiwa yang terjadi } \\
\text { dalam cerpen “Juru Masak” karya Damhuri Muhammad }\end{array}$ & 22 \\
\hline 6 & $\begin{array}{l}\text { Teks cerpen berjudul “Sulaiman Pergi ke Tanjung Cina” karya } \\
\text { Hanna Fransiswa. }\end{array}$ & $28-36$ \\
\hline 7 & $\begin{array}{l}\text { Teks cerpen berjudul “Perihal Orang Miskin yang Bahagia” } \\
\text { karya Agus Noor. }\end{array}$ & $41-47$ \\
\hline 8 & Teks cerpen “Paing” karya Edi Haryono (49-56) & $49-56$ \\
\hline 9 & Teks cerpen "Banun” karya Damhuri Muhammad . \\
\hline
\end{tabular}

Berdasarkan tabel tersebut dapat cerpen. Semua materi ajar itu merupakan benda nyata atau wujud yang merupakan dinyatakan bahwa materi ajar cerpen yang berupa fakta adalah teks cerpen, pertanyaan-pertanyaan berkaitan dengan isi bacaan, analisis struktur cerpen (fakta cerita), dan menemukan kosa kata dalam suatu kebenaran.

\section{Data-data ini menunjukkan bahwa} materi ajar cerita pendek dalam buku ini memuat beberapa cerpen yang dikutip 
secara utuh, bukan hanya cuplikan atau sinopsis. Pemuatan cerpen secara utuh akan memberikan pengalaman siswa mendapatkan pengalaman mengapresiasi cerpen secara tuntas.

2) Konsep

Konsep adalah segala yang berwujud pengertian-pengertian baru yang bisa timbul sebagai hasil pemikiran, meliputi definisi, pengertian, ciri khusus, hakekat, inti /isi dan sebagainya (Reigeluth (dalam Mudini dan Syamsurizal,2011:16). Materi ajar yang berupa konsep dipaparkan sebagai berikut.

Tabel 2: Materi Ajar yang Berupa Konsep

\begin{tabular}{|c|l|c|}
\hline No. & \multicolumn{1}{|c|}{ Data } & Halaman \\
\hline 1 & Definisi cerpen & 6 \\
\hline 2 & Ciri-Ciri cerpen & 6 \\
\hline 3 & Fungsi struktur dalam tahapan pembangunan teks cerpen. & $17-20$ \\
\hline 4 & $\begin{array}{l}\text { Jenis alur berdasarkan teknik penyampaian cerita: progresif dan } \\
\text { flashback. }\end{array}$ & 19 \\
\hline 5 & Unsur kebahasaan dalam cerpen (gaya bahasa, kosa kata) & 19 \\
\hline 6 & Menemukan gaya bahasa yang ada dalam cerpen & 19 \\
\hline 7 & $\begin{array}{l}\text { Cara menginterpretasikan makna teks cepen berdasarkan latar sosio } \\
\text { pengarang }\end{array}$ & $23-24$ \\
\hline 8 & Analisis keterkaitan isi cerita dengan kenyataan di masyarakat & 25 \\
\hline 9 & $\begin{array}{l}\text { Penjelasan memahami karakter tokoh cerpen "Sulaiman Pergi ke } \\
\text { Tanjung Cina" Karya Hanna Fransisca }\end{array}$ & 28 \\
\hline 10 & Peristiwa monologis dan peristiwa dialogis dalam cerpen. & 28 \\
\hline 11 & $\begin{array}{l}\text { Penjelasan membuat struktur cerpen "Sulaiman Pergi ke Tanjung } \\
\text { Cina" karya Hanna Fransisca }\end{array}$ & 36 \\
\hline 12 & $\begin{array}{l}\text { Penjelasan fakta cerita dalam cerpen dan tugas menganalisis fakta } \\
\text { cerita (tokoh, latar, dan alur) dalam cerpen. }\end{array}$ & $38-40$ \\
\hline
\end{tabular}

Berdasarkan tabel tersebut, materi

ajar cerpen yang berupa konsep meliputi:

definisi cerpen, ciri-ciri cerpen, struktur cerpen, alur, gaya bahasa, kosa kata, makna teks cerpen, latar belakang sosio pengarang, keterkaitan isi cerita dengan kenyataan, karakter tokoh, peristiwa monologis, peristiwa dialogis, dan konsep fakta cerita (tokoh, latar, dan alur).

$$
\text { Konsep-konsep ini telah }
$$

dipaparkan dalam buku ini dengan cukup memadai, sehingga dapat digunakan oleh siswa untuk melakukan apresiasi terhadap cerpen-cerpen yang dicantumkan dalam buku ini. 
2) Prinsip

Menurut Reigeluth (dalam Mudini dan Syamsurizal,2011:16) materi ajar yang berupa rinsip: dalil, rumus, postulat adagium, paradigm, teorema.

Materi ajar yang berupa prinsip dalam buku ini adalah struktur cerpen. Pada halaman 13-17 dipaparkan bahwa struktur cerpen meliputi: abstrak, orientasi, komplikasi, evaluasi, resolusi, dan koda. Bagian abstrak merupakan ringkasan atau inti cerita. Tahapan orientasi merupakan struktur yang berisi pengenalan latar cerita berkaitan dengan waktu, ruang, dan suasana terjadinya peristiwa dalam cerpen. Komplikasi berisi urutan kejadian, tetapi setiap kejadian itu hanya dihubungkan secara sebab akibat. Pada tahapan evaluasi, konflik yang terjadi diarahkan pada pemecahannya sehingga mulai tampak penyelesaiannya.Pada resolusi, pengarang mengungkapkan solusi dari berbagai konflik yang dialamitokoh. Resolusi berkaitan dengan koda. Ada juga yang menyebut koda dengan istilahreorientasi.
Koda merupakan nilai-nilai atau pelajaran yang dapat dipetik oleh pembacadari sebuah teks.

Materi ajar yang berupa struktur cerpen dalam buku ini agak berbeda dengan materi ajar pada teori atau buku teks-buku teks sebelumnya. Selama ini, pengertian struktur semacam itu disebut plot atau Alur. Misalnya, Asri (2010:24) menyebutkan bahwa alur dalam fiksi adalah rangkaian peristiwa atau cerita yang dibentuk oleh tahapan-tahapan peristiwa sehingga menjalin suatu cerita oleh pelaku. Teori struktur cerpen yang ada dalam buku ini perlu dikaji dengan analisis cerpen yang memadai, sehingga mendapatkan teori yang valid.

Materi ajar struktur cerpen dalam buku ini memang rancu dengan alur. Setelah dibahas panjang lebar tentang struktur cerpen, dalam buku ini justru dilanjutkan dengan pembahasan fakta cerita yang terdiri dari tokoh, latar, dan alur (38-40). Bagian inilah yang perlu mendapat perhatian penulis untuk 
dilakukan revisi dan bagi guru untuk memberikan pemahaman yang baik kepada siswa.

3) Prosedur

Materi ajar yang berupa prosedur adalah langkah-langkah mengerjakan sesuatu secara urut (Reigeluth dalam Mudini dan Syamsurizal,2011:16). Dengan demikian, materi ajar ini berupa tata urutan kerja, langkah-langkah secara runtut, atau proses melakukan sesuatu untuk mendapatkan suatu hasil.

Hasil analisis terhadap buku siswa ini menemukan dua materi ajar yang berupa prosedur yaitu rangkaian proses kreatif penulisan cerpen (hlm. 40-49) dan langkah-langkah menulis cerpen (hlm.6465). Proses kreatif penulisan cerpen yang dipaparkan dalam buku ini adalah: (a) pencarian ide terhadap karya, pengendapan dan pengolahan ide, dan (c) menuliskannya hingga selesai. Adapun materi ajar yang berupa prosedur/langkahlangkah menulis cerpen (hlm. 64-65) meliputi: (a) penemuan ide, (b) pengendapan dan pengolahanm ide, (c) menuangkannya menjadi cerita, (d) menyunting, (e) membaca keras di depan teman untuk mendapat masukan, (f) memperbaiki berdasarkan masukan teman, dan (g) mempublikasikan di majalah dinding atau media massa.

b. Jenis Materi Ajar Afektif

Reigeluth (dalam Mudini dan Syamsurizal,2011:16) menyatakan bahwa materi ajar afektif berkaitan dengan pemberian respon, penerimaan (apresiasi), internalisasi, penilaian, dsb. Dengan demikian, materi ajar pada aspek afektif berkaitan dengan penanaman atau peningkatkan sikap, tanggapan, penerimaan, atau nilai-nilai. Materi ini bisa saja terintegrasi dengan materi ajar yang berkaitan dengan aspek kognitif.

Berdasarkan hasil analisis terhadap buku siswa ditemukan materi ajar pada aspek afektif yaitu berupa pertanyaan, yaitu: pertanyaan-pertanyaan menumbuhkan kewirausahaan sebelum membaca cerpen (hlm. 7) dan pertanyaan- 
pertanyaan yang berkaitan dengan sikap, pendapat, tanggapan, harapan, dll yang dikaitkan dengan cerita setelah siswa membaca cerpen (hlm. 13). Tentu saja, jawaban pertanyaan-pertanyaan ini sangat tergantung kepada bagaimana sikap, tanggapan, kenyataan yang dihadapi siswa, dan pandangan hidupnya.

c. Jenis Materi Ajar Psikomotor

Materi Psikhomotorik terdiri: gerakan awal, semi rutin, dan rutin (Reigeluth dalam Mudini dan Syamsurizal,2011:16).Widoyoko

(2014:45) menyatakan bahwa aspek keterampilan atau psikomotor merupakan hasil belajar yang pencapaiannya melibatkan otot dan kekuatan fisik. Dengan kata lain, psikomotor adalah ranah yang berhubungan dengan aktivitas fisik. Keterampilan ini menunjukkan tingkat keahlian seseorang dalam melaksanakan suatu tugas atau sekumpulan tugas tertentu. Hasil analisis terhadap buku siswa, menemukan beberapa materi ajar pada aspek psikhomotor. Materi ajar ini menghendaki siswa untuk melakukan sesuatu. Karena materi ajar cerpen itu merupakan bagian dari pelajaran bahasa Indonesia, maka keterampilan yang dikembangkan juga tidak lepas adri keterampilan berbahasa, yaitu: keterampilan menyimak, keterampilan membaca, keterampilan berbicara, dan keterampilan menulis.

Data-data yang terkait dengan materi ajar aspek psikhomor dipaparkan sebagai berikut.

Tabel 3: Materi Ajar Aspek Psikhomotor

\begin{tabular}{|c|l|c|l|}
\hline No. & \multicolumn{1}{|c|}{ Materi Ajar } & Halaman & \multicolumn{1}{|c|}{ Keterampilan Berbahasa } \\
\hline 1 & $\begin{array}{l}\text { Tugas mencari cerpen yang bertema } \\
\text { kewirausahaan, membaca cerpen itu, dan } \\
\text { menuliskan hasil baca cerpen. }\end{array}$ & 6 & Membaca dan menulis \\
\hline 2 & $\begin{array}{l}\text { Tugas membaca cerpen berjudul "Juru } \\
\text { Masak" karya Damhuri Muhammad }\end{array}$ & 7 & Membaca \\
\hline 3 & Kerja sama membangun teks cerpen & $27-57$ & Membaca dan Menulis \\
\hline 4 & Kerja mandiri membangun teks cerpen & $57-62$ & Membaca dan Menulis \\
\hline 5 & Memproduksi teks cerpen . & $64-66$ & $\begin{array}{l}\text { Membaca, menulis, } \\
\text { berbicara, menyimak. }\end{array}$ \\
\hline
\end{tabular}




\begin{tabular}{|c|l|c|lc|}
\hline 6 & Mengubah cerita ulang menjadi teks cerpen & 118 & \multicolumn{2}{|l|}{ Membaca dan Menulis } \\
\hline & Berdasarkan data-data tersebut & dalam & mengembangkan kemampuan
\end{tabular}

maka materi ajar pada aspek psikomotor meliputi empat keterampilan berbahasa yaitu: membaca, menulis, mendengarkan, dan berbicara. Prosentase terbanyak pada keterampilan membaca. Hampir semua materi ajar psikomotor mengandung kegiatan membaca. Keterampilan selanjutnya adalah menulis yaitu menuliskan hasil membaca. Keterampilan yang tidak banyak muncul adalah berbicara dan menyimak. Dua keterampilan ini masing-masing hanya muncul sekali yaitu ketika siswa membacakan hasil cerpennya di depan kelas

\section{Relevansi Jenis Materi Ajar Cerpen dengan Kurikulum 2013}

Berdasarkan Permendikbud No. 69

Tahun 2013 tentang Kerangka Dasar dan

Struktur Kurikulum bahwa Kurikulum

2013 dikembangkan atas teori kurikulum

berbasis kompetensi (KBK). Kurikulum ini

dirancang untuk memberikan pengalaman

belajar seluas-luasnya bagi peserta didik untuk bersikap, berpengetahuan,

berketerampilan, dan bertindak.

Kompetensi dalam Kurikulum 2013 dinyatakan kompetensi inti kelas yang dirinci lebih lanjut dalam kompetensi dasar mata pelajaran (Kemendikbud, 2016:3). Kompetensi Inti adalah tingkat kemampuan untuk mencapai Standar Kompetensi Lulusan yang harus dimiliki seorang Peserta Didik pada setiap tingkat kelas atau program. Kompetensi Dasar adalah kemampuan untuk mencapai Kompetensi Inti yang harus diperoleh peserta didik melalui pembelajaran.

Kompetensi inti kelas menjadi perngorganisasi kompetensi dasar, di mana semua kompetensi dasar dan proses pembelajaran dikembangkan untuk mencapai kompetensi yang dinyatakan dalam kompetensi inti. Adapun kompetensi dasar dikembangkan didasarkan pada prinsip akumulatif, saling memperkuat, dan memperkaya antara mata pelajaran dan jenjang pendidikan. 


\section{a. Relevansi Materi Ajar dengan}

Kompetensi Inti

Kompetensi inti terdiri empat kelompok yaitu: KI-1 untuk kompetensi inti sikap spiritual, KI-2 untuk sikap sosial, KI-3 untuk pengetahuan, dan KI-4 untuk keterampilan.

Hasil analisis terhadap buku siswa Bahasa Indonesia, Ekspresi Diri dan Aklademikmenemukan bahwamateri ajar yang berkaitan dengan cerpen hanya ditemukan di kelas XI, maka kalau ditinjau relevansinya dengan KI juga dibandingkan dengan KI Bahasa Indonesia untuk kelas XI.

Seperti sudah dipaparkan di atas, bahwa materi ajar cerpen dalam buku tersebut meliputi materi ajar aspek pengetahuan (meliputi fakta, konsep, prinsip, dan prosedur), materi ajar aspek keterampilan, dan materi ajar aspek sikap. Hasil analisis dapat dipaparkan sebagai berikut.

1) Materi ajar aspek kognitif relevan dengan KI-3 yaitu memahami, menerapkan, menganalisis, dan mengevaluasi pengetahuan faktual, konseptual, prosedural, dan metakognitif.

2) Materi aspek afektif yang berupa perintah berdiskusi untuk menjawab pertanyaan-pertanyaan menumbuhkan kewirausahaan sebelum membaca cerpen (hlm. 7) dan Pertanyaan-pertanyaan berkaitan dengan sikap, pendapat, tanggapan, harapan, dll yang dikaitkan dengan cerita (halm.13) relevan dengan KI-2 yaitu menghayati dan mengamalkan perilaku jujur, kerja sama, tanggung jawab, toleransi, peduli, dan sikap sebagai bagian dari solusi permasalahan.

3) Adapun materi ajar pada aspek keterampilan relevan dengan KI-4 yaitu: mengolah, menalar, menyaji, dan mencipta dalam ranah kongkret dan ranah abstrak. 
Berdasarkan hasil analisis dapat dinyatakan bahwa semua materi ajar pada buku siswa ini relevan dengan K-I. Namun, jika dilihat dari tuntutan KI, belum semua KI tersedia materi ajarnya, yaitu KI1 yang berkaitan dengan kompetensi spiritual. Tidak ditemukan uraian, pertanyaan, atau tugas yang mengarah kepada pencapaian KI-1 walaupun memang secara konseptual KI-1 akan dapat dicapai melalui proses pembelajaran untuk mencapai KI-3 dan KI-4. Namun, nampaknya hal ini sulit dicapai karena tidak ada arahan proses pembelajaran yang mengarah ke pancapaian KI-1.

\section{b. Relevansi materi Ajar dengan} Kompetensi Dasar

Kompetensi dasar dalam Kurikulum 2013 dirumuskan untuk mencapai kompetensi inti. Rumusan kompetensi dasar dikembangkan dengan memperhatikan karakteristik peserta didik, kemampuan awal, serta ciri dari suatu mata pelajaran. Kompetensi dasar dibagi menjadi empat kelompok sesuai dengan pengelompokan kompetensi inti sebagai berikut: (1) Kelompok 1: kelompok kompetansi dasar sikap spiritual dalam rangka menjabarkan KI-1; (2) Kelompok 2: kelompok kompetensi dasar sikap sosial dalam rangka menjabarkan KI-2; (3) Kelompok 3: kelompok kompetensi dasar pengetahuan dalam rangka menjabarkan KI-3; (4) Kelompok 4: kelompok kompetensi dasar keterampilan dalam rangka menjabarkan KI-4.

Berdasarkan hasil analisis jenis materi ajar cerpen dan relevansinya dengan KI dapat dinyatakan bahwa materi ajar dalam buku teks tersebut relevan dengan KI-2, KI-3, dan KI-4. Tidak ada materi ajar yang relevan dengan KI-1. Dengan demikian, materi ajar dalam buku ini mestinya juga tidak mendukung KDKD sebagai penjabaran dari KI-1.

Berdasarkan hasil perbandingan antara jenis materi ajar dengan kompetensi dasar diapaparkan sebagai berikut. 
1) Materi ajar cerpen pada aspek kognitif relevan dengan KD pada KI1 sebagai berikut.

a) Materi ajar cerpen yang berupa fakta sesui dengan KD 3.1 (memahami struktur dan kaidah teks cerpen) dan KD 3.3 (menganalisis teks cerpen).

b) Materi ajar yang berupa konsep relevan dengan KD 3.1 (memehami struktur dan kaidah teks cerpen) dan KD 3.3 (menganalisis teks cerpen).

c) Materi ajar cerpen yang berupa prinsip yaitu rumus struktur cerpen yang meliputi: abstrak, orientasi, komplikasi, evaluasi, resolusi, dan koda. Materi ini sesuai dengan KD 3.1 (memahami struktur teks cerpen) dan 3.3 (menganalisis teks cerpen).

d) Materi ajar yang berupa prosedur dalam buku ini ditemukan 2 data yaitu penjelasan proses kreatif penulisan cerpen yang dibaca dan penjelasan tentang langkah-langkah menulis cerpen. Materi ajar ini sesuai dengan
KD 4.2 yaitu memproduksi teks cerpen.

2) Materi ajar cerpen pada aspek afektif sesuai dengan semua KD dalam KI-2, yaitu KD 2.1 (menunjukkan perilaku tanggung jawab), KD 2.2 (perilaku peduli), KD 2.3 (jujur dan tanggung jawab), KD 2.4 (perilaku peduli dan santun), dan KD 2.5 (jujur, peduli, santun). Tidak ada materi ajar yang relevan dengan KD pada KI-1.

3) Materi ajar pada aspek psikhomotor semuanya relevan dengan $\mathrm{KD}$ pada $\mathrm{KI}-4$ yaitu: KD 4.1 (menginterpretasikan makna teks cerpen), KD 4.2 (memproduksi teks cerita pendek), KD 4.3 (menyunting teks cerpen), KD 4.4 (mengabstraksi teks cerpen, dan KD 4.5 (mengonversi teks cerpen ke dalam bentuk lain).

Berdasarkan paparan hasil analisis tersebut dapat dinyatakan bahwa semua jenis materi ajar baik materi ajar pada aspek kognitif, afektif, maupun psikhomotor relevan dengan kompetensi dalam Kurikulum 2013. Materi ajar aspek afektif relevan dengan $\mathrm{KD}$ pada $\mathrm{KI}-2$ yaitu 
kompetensi dasar sikap sosial, materi ajar aspek kognitif relevan dengan KD pada KI-3 yaitu kompetensi pengetahuan, dan materi ajar aspek psikhomotor relevan dengan KD pada KI-4 yaitu kompetensi keterampilan.

Namun jika ditinjau dari KD yang ada di dalam Kurikulum 2013 mata pelajaran Bahasa Indonesia kelas XI ada KD yang tidak disediakan materinya dalam buku ini secara memadai. KD pada KI-1 yaitu kompetensi dasar pada sikap spiritual tidak ditemukan materi ajarnya dalam buku ini. Begitu pula, pada KD untuk KI-3 ada beberapa KD yang tidak ditemukan materi ajarnya di buku ini yaitu: KD 3.2 (membandingkan teks cerpen baik lisan maupun tulis) dan KD 3.4 (mengevaluasi teks cerpen berdasarkan kaidah-kaidah baik melalui lisan maupun tulis). Inilah kekurangan dari buku ini dalam materi ajar yang berkaitan dengan cerpen. Pengguna buku perlu menambah dengan sumber belajar yang lain.
Hasil analisis menemukan bahwa materi ajar cerpen dalam buku ini merupakan materi ajar yang disediakan untuk mencapai KD. Hal ini berbeda dengan temuan Sufanti (2015) bahwa ada beberapa materi sastra yang disisipkan dalam pembelajaran teks lain. Teks cerpen yang tercantum dalam buku ini memang disediakan untuk mencapai KD yang berkaitan dengan pembelajaran tekls cerpen.

\section{SIMPULAN}

Hasil penelitian ini disimpulkan sebagai berikut.

1. Jenis materi ajar cerpen dalam buku siswa Bahasa Indonesia meliputi materi ajar aspek kognitif, materi ajar aspek afektif, dan materi ajar aspek psikomotor. Materi ajar aspek kognitif meliputi: fakta, konsep, prinsip, dan prosedur. Materi ajar fakta berupa teks cerpen, pertanyaan faktual isi cerpen, dan mengidentifikasi kosa kata dan kalimat dalam cerpen. Materi ajar konsep berupa pengertian, ciri-ciri 
cerpen, struktur cerpen, unsur kebahasaan, latar belakang sosio pengarang, keterkaitan isi cerpen dengan kenyataan di masyarakat, peristiwea monologis dan dialogis. Materi ajar prinsip berupa rumus struktur cerpen. Materi ajar prosedur yaitu rangkaian proses kreatif penulisan dan langkah-langkah menulis cerpen. Jenis materi ajar aspek afektif berupa pertanyaan-pertanyaan yang berkaitan dengan sikap, tanggapan, pendapat, harapan, dan seterusnya setelah membaca atau sebelum menulis cerpen. Adapun materi ajar psikhomotor berupa tugas membangun, mengabstraksi, mengonversi, memproduksi, dan menyunting teks cerpen.

2. Semua materi ajar itu relevan dengan kompetensi Kurikulum 2013. Materi ajar aspek kognitif sesuai dengan KD pada KI-3 yaitu kompetensi pengetahuan. Materi ajar aspek afektif sesuai dengan KD pada KI-2 yaitu aspek sosial. Adapun materi ajar pada aspek psikhomotor relevan dengan $\mathrm{KD}$ pada KI 4 yaitu kompetensi keterampilan.

\section{DAFTAR PUSTAKA}

Asri, Yasnur. 2010. Dasar-dasar Apresiasi Prosa Fiksi. Bekasi: terang Mulia Abadi.

Haryati, Mimin. 2013. Model dan teknik Penilaian pada Tingkat Satuan Pendidikan. Jakarta: Referensi.

Kemdikbud. 2013. "Permendikbud No. 69 Tahun 2013 tentang Kerangka Dasar dan Struktur Kurikulum”. Jakarta.

. 2014. Bahasa Indonesia Ekspresi Diri dan Akademik, SMA/SMK Kelas X. Jakarta: Kemdikbud.

2014. Bahasa Indonesia Ekspresi Diri dan Akademik, SMA/SMK Kelas XI. Jakarta: Kemdikbud. 2014. Bahasa Indonesia Ekspresi Diri dan Akademik, SMA/SMK Kelas XII. Jakarta: Kemdikbud.

. 2016. "Peraturan Mentri Pendidikan dan Kebudayaan Nomor 22 Tahun 2016 tentang Standar Proses Pendidikan Dasar dan Menengah. Jakarta.

Kosasih. 2012. Dasar-Dasar Keterampilan Bersastra. Bandung: Yrama Widya.

2014. Strategi Belajar dan Pembelajaran, Implementasi Kurikulum 2013. Bandung: Yrama Widya. 
Kurniawan, Deni. 2011. Pembelajaran

Terpadu. Bandung: CV Pustaka Cendekia Utama.

Mudini dan Syamsurizal. 2011. Pengembangan Bahan Ajar. Jakarta: Kemdiknas.

Nurgiyantoro, Burhan. 2010. Teori Pengkajian Fiksi. Yogyakarta: Gajah Mada University Press.

Pannen dan Puspitasari. 2005. "Faktor dan Prosedur Pengembangan Bahan Ajar", dalam Pengembangan Bahan Ajar. Universitas Terbuka: Jakarta.

Sufanti, Main. 2003. "Pelaksanaan Pengajaran Sastra di SMU Muhammadiyah Se-Surakarta", Varidika, Vol. XV, Juli 2003. Surakarta: FKIP UMS.

2015. "Penyisipan Pembelajaran Teks Sastra dalam Pembelajaran Teks Nonsastra dalam Buku Siswa Bahasa Indonesia SMA", dalam Prosiding Seminar Nasional: Sastra, Pendidikan Karakter dan Industri Kreatif (Ed. Miftakhul Huda dan Miftahul Huda). Surakarta: Muhammadiyah University Press. https://publikasiums.com. Diakses tanggal 8 April 2015.

Tarigan, Henry Guntur. 2011. PrinsipPrinsip Dasar Sastra. Bandung: Angkasa.

Widoyoko, Eko Putro. 2014. Penilaian Hasil Pembelajaran di Sekolah. Yogyakarta: Pustaka Pelajar. 
Bahastra, Oktober 2016, Volume XXXVI, Nomor 1 